Annales Missiologici Posnanienses t. 20 (2015), s. 27-31

DOI: $10.14746 / \mathrm{amp} .2015 .20 .2$

WANDA BŁEŃSKA

\title{
The Witness Of A Laywoman Engaged In Medical Missionary Work In Africa ${ }^{1}$
}

[1] As far as I can remember in my childhood, there was one dream and one define purpose in my young life: to be a missionary doctor in Africa. The first step in my pre-missionary work was to plunge full heartedly into the active work of University Missionary Societies in Poland. At that time, 1928-1934, the Union of the Academic Missionary Societies was editing the "Annales Missiologicae", a journal devoted to promoting knowledge and understanding of ours and other peoples' religions, cultures and community life patterns. My participation in the life of Annales ranged from simple packing to a more responsible status of an editor.

Throwing a backward glance at our activity from a perspective of over 40 years, I must truly say that it was a very good preparation for missionary work. The interesting papers of highest standard, written by the theologians, sociologists and missionary field workers, inspired respect and understanding of other people's different convictions and customs; excellent background for future life in multiracial, multireligious Uganda. We took part in International

1 Dedykując 20 numer „Annales Missiologici Posnanienses” pamięci śp. Pani Doktor Wandy Błeńskiej, publikujemy tekst jednego z jej wystąpień, zachowanego w maszynopisie w archiwum rodzinnym Pani Doktor - za jego udostępnienie dziękujemy pani doktor Małgorzacie Pydzie. Referat ten został wygłoszony prawdopodobnie w latach sześćdziesiątych XX w., choć w chwili obecnej nie sposób ustalić dokładnej daty i miejsca jego powstania. Numery w nawiasach kwadratowych odnoszą się do numerów stron maszynopisu.

Dedicating the $20^{\text {th }}$ issue of "Annales Missiologici Posnanienses" to the memory of Doctor Wanda Błeńska we reprint here the text of one of her papers, preserved in the family archives, with gracious permission granted by Dr Małgorzata Pyda. The paper was red by W. Błeńska probably in the $1960^{\text {s }}$, however the exact date of its creation remains for the moment difficult to establish. The numbers in the brackets refer to the numbers of pages of the original typewritten text. 
Conferences, during which there was ample opportunity to exchange views and make friends with other nations, all united by the same driving spirit to spread the gospel of Christ, gospel of justice, understanding and love.

We met missionaries, who told us about the problems of people among which they worked; problems created by poverty, ignorance, disease, and more complicated ones by different patterns of social life on which our Catholic religion was to be grafted. It made us feel that we belonged to one big human family. The problems were nearly the same the world over, they merely varied in intensity.

Having finished my medical studies I tried to join the Missions, but difficulties arose. A woman had to be married or enter the convent, to be able to go into the field. The missionaries were convinced that with closed convent life of the Sisters and long distances to the nearest white community, no solitary lay worker, especially a woman, could stand the arduous life on a mission. The situation changed after the second world war and I was able, after additional training in tropical medicine, to join a missionary hospital in Uganda.

The fact that I grew up in a country where religious antagonism and colonial power did not exist, made it probably easier for me to look at other races as my equals. Cruelty of the last was washed away the feeling of white culture superiority to a very great extent and I had behind me sixteen years of medical work with people from all walks of life, united into one homogenous group of suffering humanity.

[2] In March of the Holy Year 1950 I started my work in a general White Sister's hospital, while waiting for a leprosy settlement to be built nearby. It never was, so I joined the existing leprosarium, run by the Franciscan Sisters in Buluba, on the Ugandan shore of lake Victoria.

I liked my African patients and they liked me. For many of them I was the first lay European woman they have ever seen, the one "in the dress". There was a friendly relationship with neighboring protestant mission and many Indians in the town. The fact that I was outside the sister's community permitted closer contact with non Catholic missionary societies, with which we found far more common ground and understanding than with the third large denomination of the white community, so called "golfers". Medical work formed for us a professional bridge on which we met, discussing our medical problems and forgetting completely our religious differences. As a lay doctor I formed a link between the catholic mission hospital and the government officials. At that time there was in Uganda quite a bit of unhealthy competition between the Christian denominations, all separated in their tightly woven communities.

Fortunately it was by far not everywhere, especially where the standard of work, be it hospital or school, was high enough to be appreciated by everybody. The rule, that we cannot afford to be mediocre, is as true in the multire- 
ligious mission field as it is in nonreligious part of the world. Only those, who excel in their professional skill will be accepted, respected and have a good chance of attracting other people's attention to the value of our religious convictions.

In Uganda did not exist racial discrimination, all of us, Europeans, Asians and Africans, [were] rubbing shoulders with each other during work or recreation. However, the life of a secular Christian official, doctor, nurse or teacher was more often considered as possible pattern of life for our neighbors, than the life of a priest or nun.

The indigenous African is essentially deeply religious, he believes in supreme God and in spiritual Beings, to which his forefathers belong; and he believes in their help from Beyond. The Christian religion, Catholic as well as protestant has been mostly grafted after the old beliefs have been officially rejected, and the charms burnt. How deep has our religion penetrated their lives is difficult to say as it is profitable to become Christian. In many it attained the greatest depth leading to martyrdom during the time of war and persecution, in others it remained superficial, or was rejected when confronted with polygamous life pattern of the society.

I am not sure at all that the white community as such gave a good example of truly Christian life, it means putting more stress on love than on Sunday devotions.

[3] For the Africans Christianity is a white man's religion and he feels racial dependence as long as the Church hierarchy remains European. It is to the African Archbishops, Bishops, Priests, Brothers and Sisters that will fall the difficult task of teaching religion that comes from Christ and not from $\mathrm{Eu}-$ rope.

The foundation of Catholicism rests in developing countries mostly on middle class society of a generation educated in missionary schools, professionals like teachers, nurses, social workers, often brought up by catholic parents; to them local beliefs and superstitions are strange things of the past. All secondary and nursing schools, teachers training colleges and technical courses are multitribal and to a certain extent multidenominational even if run by religious communities. For the emerging nation it is the most important factor which breaks down the tribal antagonism, still very strong in social and political life. It is this young educated generation of teachers, nurses, officials and technicians that will carry their convictions into the rural pagan society.

Catholic religion will be rejected or accepted in the form in which it has been presented, non in word but in deeds, after our pupil or colleague has scrutinized the depth of Christian life in those, who represent it.

We all join the missions or developing countries "Aid programs", full of enthusiasm to help, to teach, to cure and through lifting our brother's heavy 
burden - to prepare the way for God's grace. How much of this enthusiasm turned out to be the grain that felt into the fertile soil, bearing fruit, and how much fell among the thorns of heavy daily work and the thorns stifled it?

The small, under the tree dispensaries changed to big teaching hospitals, where order, cleanliness and high efficiency are necessarily requested together with punctuality, perfectionism and speaking the truth, three points very little appreciated by the pupils ad which are constant source of disappointment if not frank anger. Somewhere in our long way to professional perfection, the human element of love may be forgotten.

I have been working for the last 22 years in leprosy hospital, run by the Franciscan Missionary sisters. While during the first decade our efforts were concentrated on treatment of leprosy patients in special leprosy units and on training paramedical leprosy workers, in the second decade stress is laid on integration of leprosy treatment into general health service. The success or failure of the integration scheme will depend on teaching the special and general health service personnel to accept leprosy patients as ordinary patients and the general public to abandon fear and prejudice, to share willingly the waiting bench or hospital room with those, up till now regarded as rejectable and dangerous. Leprosy teaching hospital are missionary hospitals, mostly Catholic or Protestant.

We will succeed if we can teach our pupils not only to be efficient [4] professionals but to include in their medical armament the most potent psychosomatic drug called "the loving care". The pupils will to a smaller or greater extent try to follow our example, maybe even imitate our pattern of life. Will they be the so called good Catholics, regular church goers, efficient professionals, contributing to charitable projects and serving others within the normal pattern of community life? Or will they be Christ's emissaries, burning with love, ready to fight suffering and injustice wherever it lifts its ugly head; people who will go out of their way to help anybody and everybody, who looks at them with imploring eyes? People who will have the courage to intercede for others and not to abandon their cause for the sake of "peace" within the community in closer or wider sense.

We proclaim faith in our mother, the Catholic church, but is our faith deep enough to radiate to others the message of Christ's love and complete trust in fulfilment of His promise? Our Lord said: heal the sick, lay your hands on them and they will feel well. We do pray for our patients, for divine guidance in our medical work, and no doubt, many of them have been "prayed to health". We confess to God our incompetence in humble private prayers in the church, at home and perhaps silently at the bed side; but who of us has the deep faith that transfers the mountains? Who of us dares to say in the hospital full of sceptics and unbelievers, the simple words: "we have done all we can and we have 
failed! But God, our Lord in Whom we believe, can and will help you, get up and walk! If we can do that we can compute with local healers, diviners, with doctors and we can become true propagators of our Faith. But there is always that cautious "if God wills" to help us in case of failure, the same failure that beset Peter, walking on the waves.

Another problem, which seems to be unsurmountable, is tremendous difference in the standard of life. What is the proper pattern which we should teach our African brothers to accept as standard civilized life of cleanliness, safety, healthy nutrition, with their low income ad "extended families", and where does luxury begin? They will learn it from us not by what they hear but by what they see. It is difficult to teach our neighbors love with our stomachs full and hungry people around.

We can share our goods with some but not with hundreds. There is somewhere a limit to what we can and should do but I don't think that we usually reach that limit, definitely not in too many cases.

The political leaders of emerging countries are pupils of missionary schools. They may or may not be anti-Christians but are to a great extent anti whites; they neither reject the essence of our teaching nor our help, but our supremacy. To be fully accepted, we should work with them rather than for them and that means tolerance, patience and humility in sharing our technical and spiritual knowledge.

[5] To the devoted missionaries in the third world goes the merit of bringing light into the darkness, of lifting up our brothers to face and fit into the rapidly growing world of self-dependence, technique and science. The old beliefs, customs and life patterns are crumbling down and unless we fill that gap with new life of Christian Faith and love, the Enemy can take over, spreading frustration, despotism, hatred.

It is the duty of every Catholic whether secular or religious, wherever his place, to share with others the precious gift of our Faith, to help, however little we can in the God's most important task of consecration mundi. 


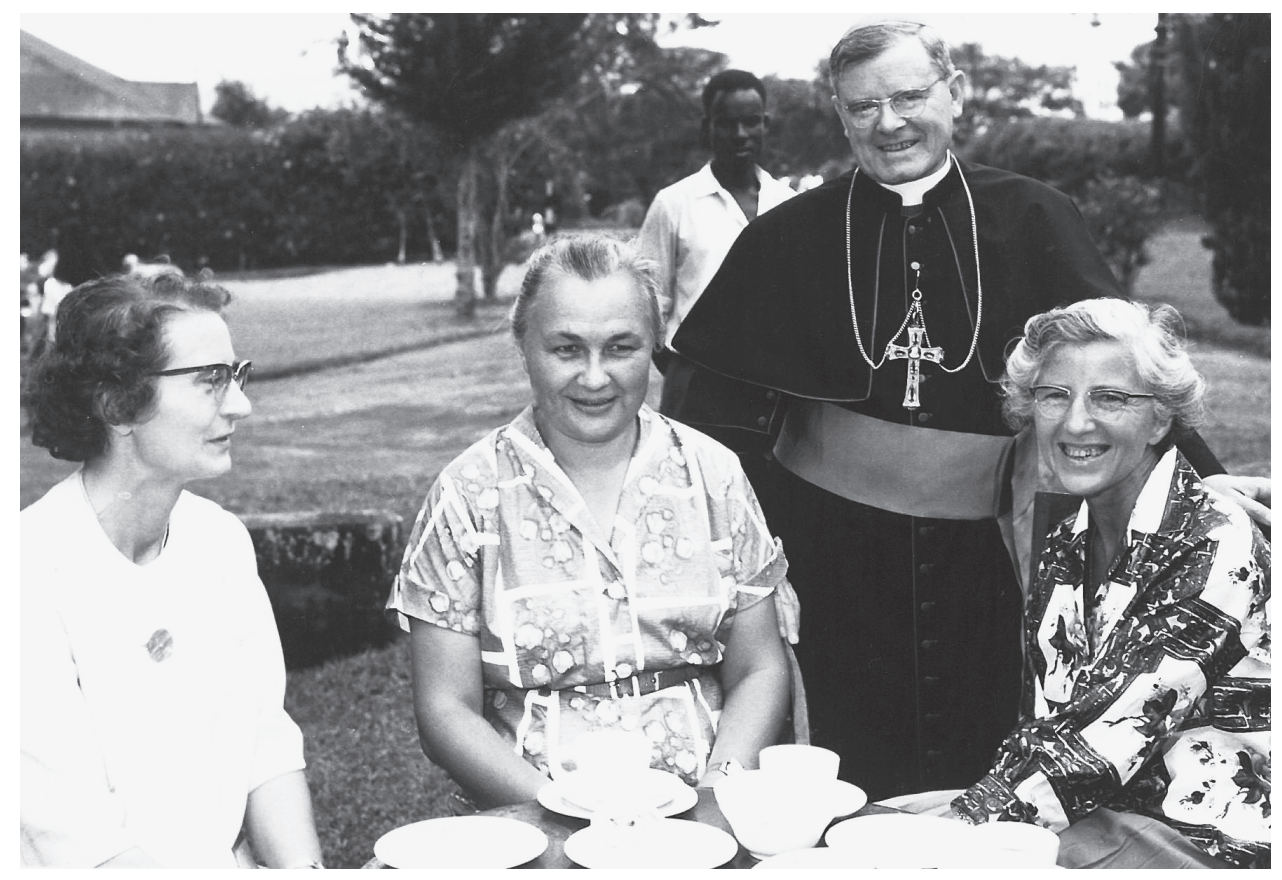

